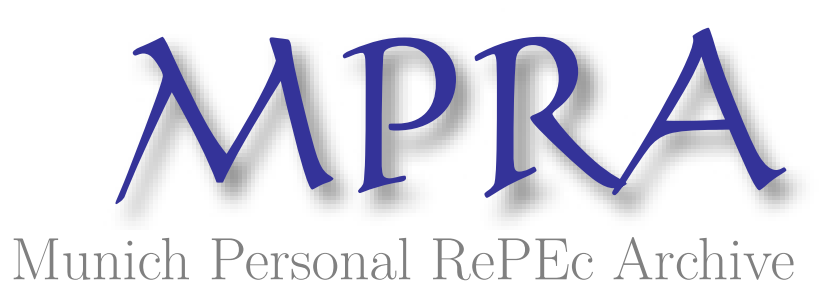

\title{
The effect of decentralisation on access to sanitation and water services: An empirical test using international data
}

Taiwo, Kayode

December 2020

Online at https://mpra.ub.uni-muenchen.de/105426/

MPRA Paper No. 105426, posted 31 Jan 2021 11:06 UTC 
The effect of decentralisation on access to sanitation and water services: An empirical test using international data

Kayode Taiwo*

This version: December 2020

\begin{abstract}
Decentralisation promises efficiency gain and improved access to public goods and services, especially at the local level. Under decentralised governance arrangement, regional and environmental peculiarities are given prominent consideration in delivering public goods and services. Given the impact of the environment in influencing sanitation and water services, particularly water provision, this study examines the effect of decentralisation, as measured by revenue share and expenditure share, on improved access to sanitation and water services. Exploiting the variation in improved access to sanitation facilities and water sources using a static panel data estimator, this study's empirical results suggest a positive impact of decentralisation on the improved access to sanitation and water services. The positive effect is larger in rural areas vis-à-vis the country level and urban areas. The study reveals that wealth and institutional factors are also important to improve access to sanitation and water services.
\end{abstract}

Keywords: Decentralisation, Subnational government, Sanitation, Water, Panel data

Je/Classification: $\mathrm{H} 77, \mathrm{O} 18$

*Núcleo de Investigação em Políticas Económicas e Empresariais (NIPE), School of Economics and Management, University of Minho, Portugal; Department of Economics, Adekunle Ajasin University, Nigeria. Email: kayode.taiwo@hotmail.com. Special credit is due to Linda Veiga for support and inputs. I also thank Miguel Portela, Ivo Bischoff, and an anonymous reviewer for their helpful comments. 


\section{Introduction}

The United Nations (UN) agencies such as the World Health Organisation (WHO) and the United Nations Children's Fund (UNICEF) started data collection on drinking water and sanitation in 1990. In 1990, 77 percent of the world had access to drinkable water from improved sources, but only 54 percent had access to improved sanitation facilities (WHO, 2008). Since that year, the WHO/UNICEF Joint Monitoring Programme (JMP) had been in place to monitor and keep data on countries' progress in meeting drinking water supply and availability of sanitation facilities. Predominantly in the 1990s, lack of drinking water and inadequate sanitation facilities were global challenges. The trend in the data reported from many countries might have informed the inclusion of access to drinkable water and sanitation facilities among the targets of Millennium Development Goals (MDGs).

In 2000, Member States of the UN approved the Millennium Declaration, which was translated into eight MDGs. This was to bring an end to poverty in all its ramifications, including lack of access to safe drinking water and sanitation facilities. Under the MDGs program, the targets for water and sanitation were measured in terms of the population's proportion using improved sources of drinking water and the proportion of the population having access to improved sanitation facilities, respectively. According to the UN (WHO/UNICEF, 2015), the improved drinking water sources include piped water, protected wells, and other suitable drinking water sources. Improved sanitation facilities are sanitation facilities that guarantee the hygienic separation of human excreta from human contact. At the time of winding up the MDGs program in 2015 to be supplanted with Sustainable Development Goals (SDGs) starting from 2016, the UN declares in her MDGs report that 147 countries have met drinking water target, 95 countries have met the sanitation target, and 77 countries have met both globally. Still, many people around the world are without access to drinkable water and improved sanitation facilities. Around the world, 2.1 billion people are without potable water at home, while 4.5 billion people do not have access to toilets at home for safe disposal of excreta (WHO/UNICEF, 2015). The inability to eradicate problems of poor sanitation and lack of drinking water has inevitably made the inclusion of water and sanitation, including improved hygiene that was not part of the MDGs, as goal number 6 in the SDGs program that encompasses 17 goals. The SDGs program aims to go beyond MDGs' achievements on poverty and hunger in all ramifications by 2030 (WHO/UNICEF, 2017).

The global efforts to eradicate poor sanitation and lack of drinking water is not unconnected with their significant knock-on effects on the economy. Many people die worldwide due to causes directly linked to poor sanitation and lack of drinkable water. According to WHO (2008), half of the child malnutrition is directly linked to unsafe water, inadequate sanitation facilities, and poor hygiene. It has also been 
established that the loss of productivity arising from water and sanitation-related infections results in about 5 percent loss in many countries' GDP, especially in developing countries (WHO, 2012). Considering these vast economic losses, UN agencies are encouraging nations to avoid these losses by investing in drinking water and sanitation services. They are also mobilising funds from donors to assist needy nations in meeting the cost of investments in water and sanitation services. WHO (2012) reports that every $\$ 1$ invested in water and sanitation-related services brings a return of about $\$ 4$ in productivity gain. Despite the apparent benefits, many nations cannot meet the enormous investment required for water and sanitation provision. The gap in meeting these essential services globally under the WASH (Water, Sanitation, and Hygiene) targets of SDGs 6 has been put at $\$ 1.7$ trillion (Hutton \& Varughese, 2016).

The gloomy situation of water and sanitation services around the globe has motivated this work. Most of the areas that are less served in many countries are located outside the urban areas. In response to this, we set to examine if the problems can be tackled through the governance architecture of decentralisation. Environmental factors significantly affect these services, and subnational governments are best positioned to address the issues. Besides, we observe that location-specific studies have been conducted on water and sanitation in the context of decentralisation (Lary-Adjei \& van Dijk, 2012; Asthana, 2003; Oates, 2002; Dinan, Cropper \& Portney, 1999). However, despite the problems posed by the lack of water and sanitation services globally, there is a dearth of cross-country studies conducted on the impact of decentralised governance architecture on sanitation and water services. Therefore, this study is an attempt to fill this gap. Additionally, political competition can affect service delivery in a country (Arvate, 2013). The study tries to discern the impact of political competition on the outcome of interest through the interaction of political competition with measures of decentralisation. The study finds that decentralisation leads to improve access to sanitation facilities and water sources. The effect is larger in rural areas vis-à-vis the country level and urban areas. The level of wealth and institutions are crucial contributory factors in the provision of the services. However, the effect of political competition on improved access to sanitation facilities and water sources through interaction terms is not identifiable.

The organisation of the study is structured as follows. Section two discusses the concept of decentralisation and its measurement, including relevant literature to the study. Section three provides information on methodology and data, econometric strategy, and estimation issues. While in section four, the results of the econometric estimation are analysed. The study is concluded in section five. 


\section{Literature review}

\subsection{Decentralisation: conceptual and measurement issues}

Decentralisation describes the process of transferring fiscal powers from the central government to subnational governments to increase the provision of public outputs and tailor such outputs to local needs. This definition is limited to the fiscal perspective of decentralisation. There are political and administrative views of decentralisation. The state's constitutional structure addresses the political view of decentralisation; a state is considered decentralised when it operates a federal constitution. Also, the process of the emergence of local officials is factored into the political definition of decentralisation. From the administrative perspective, the power of the lower levels of government determines administrative decentralisation (Martinez-Vazquez, Lago-Penãs \& Sacchi, 2017). The capacity of subnational governments in making fiscal decisions independent of the central government is important. By and large, decentralisation, the transfer of power to local people to run their governments and provide their public goods, is an instrument being employed to improve the public sector's performance (Oates, 1972, 1999). ${ }^{1}$ Decentralisation is a means to accelerate development, especially in developing nations (Smoke, Loffler \& Bossi, 2013). Based on economies of scale, which arises from externalities/spillovers and factors mobility across jurisdictions, central planning may be preferred to decentralisation as the central government may be able to adequately internalise the effects of economic activities (Veiga et al., 2015). Based on information asymmetry and costs and benefits, ${ }^{2}$ it appears more reasonable to allow for local provision of public services. However, issues of information and costs and benefits may appear stronger in some cases, which may justify the local provision of public goods and the need for decentralisation. ${ }^{3}$

Decentralisation assumes a different meaning in economics as compared with political science. The term does not depend on the constitutional structure; though, the constitution expressly specifies the power and autonomy of various levels of government in a federation. ${ }^{4}$ The extent of the power exercised by lower tiers of government varies from country to country in both federal and unitary states and may change in either direction over time. A federal state by the constitution (e.g., Nigeria) may be less decentralised than a nominally unitary state (e.g., the United Kingdom). By and large, in economics, all public sectors are more

\footnotetext{
${ }^{1}$ The literature on multilevel government recognises three types of decentralisation, regardless of the state's constitutional structure: deconcentration, delegation, and devolution, from the weakest to the strongest. All forms of decentralisation involve the transfers of fiscal power and authority over certain functions to subnational governments. However, the power to act without recourse to the central government varies under each form of decentralisation (see Blume \& Voigt (2011) for some details).

${ }^{2}$ This may depend on the nature of goods and/or services being produced.

${ }^{3}$ From a functional perspective, social protection is the least decentralised function, while subnational governments play significant roles in services such as health, education, housing, and environmental protection (Veiga et al., 2015).

${ }^{4}$ Decentralisation is not a one-size fit all affair. There is great diversity in this issue. Gómez-Reino and Martinez-Vazquez (2013) report in a study involving a sample of 197 countries that 101 countries have two levels of government, 50 countries have three levels of government, 35 countries have one, and 10 countries have 4 tiers of government. Two extreme cases feature in the study: Kiribati has no local government, while India has more than 240,000 local governments.
} 
or less decentralised as different levels of government are in charge of the production of various public goods and services with different levels of authority (Oates, 1972, 1999). Governments at various levels exercise some fiscal authority over their jurisdictions for multiple government levels to perform their duties. These include the power to tax and raise funds through borrowing. Tax-assignment addresses the issue of the vertical fiscal imbalance in revenue allocation in a federation. Issues of capacity, cost, and efficiency are factors in assigning tax functions to various tiers of government. The central government is usually empowered to raise certain taxes because of the economy and efficiency of doing so at the central level. This leaves the central government with a large share of revenues from taxes. Hence, the need for the central government to make intergovernmental grants to lower tiers of government. Also, the horizontal fiscal imbalance at subnational levels in terms of revenue-generating capacity and the need for functions at subnational units to be efficiently and effectively performed requires transfers to be made to them.

Decentralisation may be measured in different ways, depending on the definition and perspective. It is measured using fiscal decentralisation indicators such as ratios of subnational-centre revenues, subnationalcentre expenditures, and vertical imbalance. Decentralisation is also measured using political decentralisation indicators such as local elections and political divisions and structural and administrative decentralisation indicators (Martinez-Vazquez \& Timofeev, 2010; Blume \& Voigt, 2011; Dzobek, Mangas \& Kufa, 2011; Martinez-Vazquez et al., 2017). These indicators are measured in several ways. According to Martinez-Vazquez et al. (2017 p. 1098), "no single measure of decentralisation can capture all the multiple dimensions that decentralisation offers." Notwithstanding the shortcomings of any of these measures, this study will use the fiscal decentralisation indicators in econometric estimation.

Specifically, the ratio of revenues of subnational governments to total government revenues (revenue share) and the ratio of expenditures of subnational governments to total government expenditures (expenditure share) will be used in this study as measures of decentralisation. These are constructed from the IMF's Government Finance Statistics (GFS). There are measurement issues with these measures of decentralisation. ${ }^{5}$ Even so, these measures of decentralisation constructed from the GFS data are widely used in empirical studies. The major problem with these measures is the aggregation of data in the GFS. Information at the subnational level is aggregated, making it difficult to account for heterogeneity between tiers and within tiers of government under decentralisation. Also, there is no known measure to account for the efficiency of government funds at any of the tiers of government. The reportage of data varies across

\footnotetext{
${ }^{5}$ There are attempts at developing other measures. These are also not without their challenges. See Martinez-Vazquez et al. (2017 p. 1098-1099) for a recent discussion of these issues.
} 
countries and regions. Developed economies report more data than developing economies. This introduces a selection bias into the information.

\subsection{The impact of decentralisation in other government policy areas}

Decentralisation helps to accelerate development, tailor public outputs towards local needs, and bring government closer to the governed (Oates, 1999). The effects of decentralisation in many other policy areas have been studied. These policy areas include health, education, governance, growth, poverty, and inequality, to mention but a few. On a general note, the result is mixed for the effect of decentralisation on growth (Davoodi \& Zou, 1998; Thiessen, 2003; Thornton, 2007; Rodriguez-Rose \& Ezcurra, 2011; Gemmell et al., 2013). Both studies by Sepulveda and Martinez-Vasquez (2011) and Sacchi and Saloti (2014) fail to establish that decentralisation reduces poverty and inequality. However, studies have established that decentralisation produces positive impacts in the service areas, especially in providing health services and education. Fiscal decentralisation improves life expectancy and other health outcomes and reduces infant mortality rates (Cantarero \& Pascual, 2008; Rubio, 2011; Soto et al., 2012; Faguet \& SánChez, 2014). Though, Brock et al. (2015) establish that decentralisation does not reduce infant mortality in China.

The effect of fiscal decentralisation is positive on education and educational outcomes (Barankay \& Lockwood, 2007; Falch \& Fisher, 2012; Diaz-Serrano \& Meix-Llop, 2012; Faguet \& SánChez, 2014). Additionally, decentralisation has also been found to be of crucial importance in improving governance. Fiscal decentralisation increases the quality of governance (Kyriacon \& Rosa-Segalés, 2011), reduces both transnational and domestic terror attacks (Drucker \& Fisher, 2010, 2011), and correlates positively with trust in government (Lightart \& Oudheusden, 2015). Under an ideal decentralised system, substantial resources are devolved to the local government. Where this happens, fiscal decentralisation should improve governance outcomes. On the dark side of decentralisation, Reinikka and Svensson (2004) posit that decentralisation may bring about local capture. This occurs when resources transfer to subnational governments for developmental purposes are cornered by the local elites for their narrow interests (Prud'homme, 1995). Excessive fragmentation resulting from decentralisation sometimes leads to loss of economies of scale in producing goods and services. These undesirable outcomes of decentralisation may have informed the position of Ahmad et al. (2006) that the process of implementing decentralisation can be as important as the design of the system in influencing service delivery outcomes. 


\subsection{Sanitation and water services: A survey}

Water and sanitation services are essential in reducing morbidity and in improving health, welfare, and development. Koola and Zwane (2014 p. 477) posit that "improving health and mitigating diarrheal morbidity is the underlying rationale for water and sanitation." Alsan and Goldin (2019), using historical data of the late nineteenth and early twentieth centuries, conclude that the combination of sewerage and safe water treatment lowers under-five child mortality in Massachusetts, United States of America (US). This finding is similar to the result obtained by Jaadla and Puur (2016) for Tartu, Estonia. Gamper-Rabindran at al. (2010) find that provision of piped water reduces under-1 infant mortality in Brazil. This occurs through improvement in the water supply, which raises the level of wellness of infants. Fiscal decentralisation is associated with lower infant mortality rates (Asfaw et al., 2007; Robalino, Picazo \& Voetberg, 2001), which may be attributed to the role of subnational governments in the provision of sanitation and water services.

The level of political competition can influence the responsiveness of the government at any administrative level. Provision of public services, including water and sewerage services, has been found to respond to electoral competition at the local level in Mexico, particularly in Jalisco and Michoaćan (Hiskey, 2000) and Brazil (Arvate, 2013). Cleary (2007) concludes that electoral competition does not impact the municipal government performance, but measures of electoral participation cause improved performance in terms of the provision of public goods. The study suggests that municipalities with higher electoral participation by the citizens do better in providing services by connecting more houses with sewerage, and provision of potable water. However, Rosenzweige (2015) finds evidence that electoral competition improves public service provision, including pipe-borne water in Tanzania. Granados and Sánchez (2014) observe that improvement in water and sanitation services is associated with a reduction in child mortality where municipalities directly provide the services in Colombia, in contrast to municipalities that engage private companies. They recommend the direct provision of water and sanitation services by municipalities because the political interest of remaining in the office encourages political officeholders to provide better services. Zewari et al. (2011) argue that states in the Middle East and North Africa (MENA) make a poor investment in water and sanitation facilities, thereby failing to provide the services where they are most needed, especially in informal settlements. Besides, they observe that centralisation of water and sanitation infrastructures contribute to the poor quality of services provided, while some areas are denied access to services.

Veiga et al. (2015) posit that decentralisation is emerging as a preferred governance architecture in providing essential services such as water and sewerage services. The central goal of decentralisation is the exercise 
of political power by local actors over what and how goods and services are produced at the local government. Indeed, the idea behind decentralisation is that local governments can improve welfare and development when resources of various jurisdictions are appropriately matched with their needs (Oates, 1972, 1999). On the arsenic rule standard in drinking water in the US, Oates (2002) argues that the standard should suit each district's circumstances. This was in response to the centralised standard set by the US Environmental Protection Agency (EPA). The implication of this is that provision of water and sanitation services should be decentralised given the impact of natural/environmental factors in delivering these services. In effect, decentralisation of water and sanitation services will improve the coverage of the services because drinking water availability and quality are highly susceptible to environmental quality and standards.

Dinan et al. (1999) argue that the imposition of a uniform standard in a federal state without consideration for each locality's cost-benefit criterion results in inefficiency and welfare losses in water provision. The view is supported by Chattopadhyay's (2012) submission that the central planning process leads to inadequate provision of public goods and low quality of life. Ranganathan et al. (2009) submit that decentralised water and sanitation services are adopted in Indian cities to fill the gap in these essential services. Laryea-Adjei and van Dijk (2012) conclude that decentralisation leads to improved water and sanitation services in Ghana. Awuah et al. (2009) observe that decentralisation aids the provision of services in Temale and Savelugu-Nanto. Faguet and Sánchez (2014) note that decentralisation in Colombia improves access of the poor to water and sanitation services under public health facilities.

Montgomery and Elimelech (2007) argue in favour of a decentralised approach in the provision of water and sanitation services for developing countries. They note that the implementation of large and centralised treatments is expensive and problematic in terms of maintenance. At the heart of this is the issue of efficiency in asset utilisation. The persistent water scarcity spurs decentralised management of river basin water resources (Dinar at al., 2007). This, in many cases, leads to improved water provision. Availability of water and adequate provision of sanitation facilities have significant knock-on effects on the economy. With decentralisation, these services can be made available at every subnational unit in any geopolitical space, and all the benefits of the availability can be internalised. It guarantees efficiency in infrastructural investment, distribution, and costs. Though Asthana (2003) finds that the efficiency of water utilities in expense and asset utilisation in Central India is poor, this should not be the basis of rejection of decentralisation as a governance strategy in alleviating the problems of poor sanitation and water scarcity around the world. The environmental standard and quality of water are not the same across the studied 
areas. Thus, financial/operating efficiency cannot be the only basis for measuring the gain of decentralisation. The level of a contaminant in each decentralised unit will impact operating efficiency and profitability. This will also result in welfare losses if not sufficiently factored into the service that Asthana's (2003) study did not adequately consider. Herrera (2014) argues that the simultaneous implementation of market policies with decentralisation will harm decentralisation of sanitation and water services in Mexico. Herrera's (2014) conclusion negates the market efficiency criterion of Asthana (2003).

\section{Methodology}

\subsection{The empirical model}

The model in equation (1) has been specified to investigate the relationship between decentralisation and water and sanitation services. A similar model has been used in a study by Sepulveda and Martinez-Vazquez (2011) to study the impact of decentralisation on poverty and income inequality.

$$
\begin{gathered}
y_{i t}=\beta M F D_{i t-1}+\rho \text { Political Competition }_{i t}+\psi \text { Political Competition }_{i t} * \text { MFD }_{i t-1} \\
+\gamma \text { Control }_{i t}+\alpha_{i}+\xi_{i t}
\end{gathered}
$$

where $i$ indexes a country and $t$ represents a year. The parameters of interest to be estimated in equation (1) are $\beta, \rho, \psi$, and $\gamma . \alpha_{i}$ is the individual effect of country $i$, it becomes $\alpha$, homogenous intercept term for each country $i$ when the model is estimated using pooled ordinary least squares (OLS); while, $\xi_{i t}$ is the error term. In equation (1), the dependent variable, $y_{i t}$ represents two variables, sanitation facilities and water sources. In the first case, the dependent variable is the percentage of the total population with improved access to sanitation facilities for a country in a particular year. In the second case, the dependent variable is the percentage of the total population with improved access to water sources for a country in a particular year. MFD implies measures of fiscal decentralisation in a one-year lag. Two measures of decentralisation are considered in this study: Revenue share is the ratio of revenues of subnational governments to total government revenues, and Expenditure share is the ratio of expenditures of subnational governments to total government expenditures. Since the decentralisation policy may not have a contemporaneous effect on the improved access to sanitation and water services because of policy lag, a one-year lag of the decentralisation variable is introduced. Each of the dependent variables is regressed on 
measures of decentralisation, along with other covariates. If decentralisation improves access to sanitation and water services, the a priori expectation of the sign associated with the decentralisation variables is positive in the model.

The responsiveness of government is linked to political competition (Hisky, 2000; Arvate, 2013; Rosenweig, 2015). A way of testing the government's responsiveness in this study is through the interaction of a dummy variable for political competition with measures of decentralisation. The dummy, Political competition, is generated from "Polity2" in Polity IV data. ${ }^{6}$ The dummy variable is based on the work of Aidt and Eterovic (2011). In this study, the "Polity2" score for a country in a particular year is normalised to 1 for a less politically competitive country that scores between -10 and 0 ; otherwise, a country is assigned a dummy of 0 . The a priori expectation for the sign of the dummy variable's coefficient is negative because the nonpolitically competitive countries will care less about the people's welfare. Also, we interact the dummy with the MFD. The interaction term makes the impact of decentralisation on sanitation and water services dependent on the level of Political competition. Thus, it measures the partial effect of MFD when Political competition is 1 . It explains the impact of decentralisation on sanitation and water services in states that are less politically competitive. The impact of decentralisation on sanitation and water services for less politically competitive countries will be determined by the joint coefficients of decentralisation as measured by either Revenue share or Expenditure share with the coefficient of the interaction term. However, the expected sign for the coefficient associated with the interaction term is not definite. This stems from implications of the political environment on decentralisation arrangement for measures of decentralisation.

Other covariates in the model are Government size, Log GDP per capita, Log population density, Bureaucratic quality, Democratic accountability, Globalisation, and Internal conflict. The size of government is constructed from the WDI as a proportion of the general government final consumption expenditure to gross domestic product (GDP).? This variable is important in explaining the production of public goods and services, namely water and sanitation. Thus, the expected sign of the coefficient of this variable is positive. The Log GDP per capita is the log of GDP per person in a nation in constant term. This is a measure of the level of development and the welfare level in any economy. It also represents the average income per person in a year. This is expected to be positively related to improved access to sanitation and water services. The richer a country is, the higher is the likelihood that essential services such as sanitation and water services are adequately provided to the entire population. The expected sign of the coefficient of this variable is positive. The Log population density is the log of the ratio of the total population to land area (in square

\footnotetext{
- See Centre for Systemic Peace, http://www.systemicpeace.org/inscrdata.html.

Both general government final consumption expenditure and GDP are in 2010 US\$ constant term.
} 
kilometre) of a country. The population density may drive the provision of essential services such as sanitation and water services. A high population density indicates pressure on public facilities, which requires the government to make more investment in basic services to meet the population's needs. Thus, the expected sign of the coefficient of this variable is positive.

Bureaucratic quality is a measure of institutional quality in a country. It is an indicator of the stability of bureaucracy. It denotes the risk of policy reversal in a country, often caused by political pressure on public service officers. A high-quality public service that ensures smoothness in government operations is an asset to any nation as public service officers implement and monitor public projects. The data is obtained from ICRG, and the score for this variable ranges from 0 to 4 . The high-risk countries with poor bureaucratic quality are scored 4. In contrast, the low-risk countries that have their public services insulated from political pressure are scored 0 . Thus, it is expected that Bureaucratic quality and provision of services are negatively correlated. Democratic accountability spurs the provision of public goods and services. It is also an institutional factor; the data is obtained from ICRG with a score ranging from 1 to 6 . It measures government responsiveness to its people under different democratic practices from alternating democracy to autarchy. It is also a measure of the risk of collapse of a government. Countries with the lowest risk of government collapse receive the highest score of 6 , while high-risk countries receive the lowest score of 1 . This variable is expected to be positively correlated with improved access to sanitation and water services.

Globalisation is a composite measure of the economic, political, and social aspects of globalisation. It is an indicator of how countries are opened to global influence. Because of the information globalisation, events in a country are not independent of events in another country. As people share information about their development, it is expected that this will impact the provision of services in another country. Indeed, the influence of globalisation may have motivated the UN MDGs (and now SGDs) to ensure a certain minimum standard of public services across the globe. This may have necessitated the monitoring of the provision of sanitation and water services. Thus, this variable is expected to be positively correlated with improved access to sanitation facilities and water sources. Internal conflict is a measure of internal strife's risk and its impact on governance with subcomponent issues of civil war and coup threat, terrorism and political violence, and civil disorder. The absence of peace is a significant threat to governance, which eliminates all possibilities for development. Thus, no improvement in access to sanitation and water is possible in the absence of peace. According to the definition of ICRG, a high-risk country is scored 0 , while a low-risk country is scored 4. It is expected that this will negatively correlate with the improved provision of sanitation and water services in a country. A summary of definitions and sources of the variables is provided in Table $A$ in the Appendix. 


\subsection{Data}

This study's data is panel data covering a period of twenty-four years from the year 1991 to the year 2014. This covers a long period over which the UN MDGs are vigorously pursued to reduce the problems of lack of drinkable water and poor sanitation facilities worldwide. Though data on improved access to drinkable water and sanitation is available for almost all the world countries, the sample size for this study is reduced to 68 because some countries did not report any data in GFS. Many of the countries in the sample are highincome countries. ${ }^{8}$ These countries had attained considerable access to drinkable water and sanitation facilities when the data collection started. Notwithstanding, they stepped up the provision of these services to attained full coverage in their countries. The data on improved access to sanitation and water is from the UN database reported in World Bank Development Indicators (WDI). Like the GFS data, the UN data on sanitation and water services is vitiated by aggregation and lack of quality definition. While it gives the picture at the national level, it does not reveal households and communities' situation. Though the data is disaggregated to provide information on the rural and urban areas, the information remains aggregated over these units. Additionally, there is a claim that the figures are overstated and do not represent the actual situation (Zawahri et al., 2011). The summary statistics of the data is displayed in Table 1 below.

Table 1: Summary statistics, 1991 - 2014

\begin{tabular}{lcccc}
\hline \hline Variable & Mean & St. Dev. & Min & Max \\
\hline Improved access to sanitation, country level & 88.54 & 16.76 & 16.90 & 100 \\
Improved access to sanitation, urban areas & 92.05 & 11.59 & 43.00 & 100 \\
Improved access to sanitation, rural areas & 82.73 & 23.51 & 5.60 & 100 \\
Improved access to water, country level & 95.34 & 7.19 & 60.90 & 100 \\
Improved access to water, urban areas & 98.20 & 3.60 & 67.50 & 100 \\
Improved access to water, rural areas & 90.47 & 13.51 & 41.90 & 100 \\
Revenue share & 26.64 & 14.53 & 0.82 & 85.43 \\
Expenditure share & 24.29 & 14.28 & 1.81 & 76.61 \\
Government size & 18.71 & 5.07 & 6.83 & 37.74 \\
Log GDP per capita & 9.53 & 1.17 & 6.32 & 11.61 \\
Log population density & 4.14 & 1.23 & 0.50 & 6.24 \\
Bureaucratic quality & 2.89 & 1.04 & 0.00 & 4.00 \\
Democratic accountability & 5.02 & 1.26 & 1.00 & 6.00 \\
Globalisation index & 71.65 & 14.51 & 31.08 & 92.84 \\
Internal conflict & 10.01 & 1.64 & 2.33 & 12.00 \\
Political competition & 0.07 & & 0 & 1.00 \\
\hline \hline
\end{tabular}

Notes: The data is sourced from UN, IMF, ICRG, WBI, Polity IV, and KOF index of globalisation. The Log GDP per capita is the log of Gross Domestic Product per capita (GDP). Log pop. density refers to log population density. Democratic acct. means democratic accountability. $\mathrm{N}=1050$. $\mathrm{N}$ is the number of observations for each variable for all countries. Source: Author's computation.

s This classification is based on the World Bank classification for the year 2016 using the 2014 data. 


\subsection{Econometric issues and specification tests}

Given the longitudinal dimension of the data for this study, three estimators are employed in the econometric estimation of equation (1). These estimators are pooled ordinary least squares estimator (OLS), fixed effects estimator (FE), and random effects estimator (RE). A series of specification and diagnostic tests are conducted to check for issues that may negatively affect the parameter estimates' consistency and efficiency for this study. Correlation analysis of the variables obtained from the correlation matrix indicates that $\mathrm{Log}$ GDP per capita and Globalisation are highly and positively correlated in the region of 0.87 . All correlation coefficients for other variables are below 0.87 .

Two tests are employed to check for the existence of the problem of heteroskedasticity in the data. The study exploits White's (White, 1980) test for heteroskedasticity. This test is robust to heteroscedasticity with errors that are not normally distributed and variances that are not linear. The test suggests a rejection of the null of homoskedasticity for all the models with Revenue share and Expenditure share among the regressors. Additionally, the modified Wald test for groupwise heteroscedasticity (Greene, 2017) is employed to investigate the heteroscedasticity problem in the data further. The null of homoskedasticity is rejected for all the models. The Wooldridge test for autocorrelation in panel data (Drucker, 2003; Wooldridge, 2010) is employed to test for the problem of autocorrelation in the data. The null hypothesis of no serial correlation is rejected for all the models. These identified problems can impact the efficiency and consistency of the regression estimates of this study. A clustered robust standard error at the country level is reported for all the regression estimates. The clustered robust standard errors are robust to the problems of heteroskedasticity and autocorrelation within a country but not across countries.

\section{Empirical strategy and results}

OLS is consistent and unbiased if there is no endogeneity problem or no covariance between regressors and the error term. If no covariance condition is satisfied, it provides the response variable's effect on the unconditional population mean of the independent variable based on the law of iterated expectation. Two problems plague OLS: common intercept term for all the countries and the requirement that regressors and the error term are contemporaneously uncorrelated, which is always violated due to the country-specific error's autocorrelation. It will be incorrect to assume that the coverage level achieved in the provision of services in the current period is independent of previous periods. Therefore, a strategy to correct 
autocorrelation is implemented in OLS by obtaining clustered robust standard errors for efficient and consistent estimates.

The FE estimator helps control for the unobserved individual country-specific effects, which could have resulted in omitted variables in a panel data regression. The individual country-effect may vary over countries and a major improvement over OLS. The FE estimator can capture observable and unobservable countryspecific and time-invariant differences. The FE estimator requires that there is no correlation between independent variables and the within-entity error term. The expected value of the deviation from the mean of the regressors and the error term is zero. This subsumes the exogeneity condition requires that the regressors' current, future, and past values do not depend on the error term. This condition is necessary for an unbiased estimate of the individual effects (fixed effects) under this estimator. The RE estimator is more efficient than both OLS and FE in combining matrix weighted information from both within and between variances of the data. The central assumption under the RE estimator is the independence of the regressors and the composite error term. That is, the regressors are not correlated with both country-specific and remainder errors in this model. The conditions must also be fulfilled to ensure that the least square estimates of the coefficients are unbiased and consistent. However, the standard errors of the least square estimator are wrong. A more efficient estimate of the standard errors can be obtained from the (feasible) generalised least squares (GLS) estimator by exploiting the structure of the variance-covariance matrix of the error term (Verbeek, 2017). This requires that the regressors are not correlated with the individual and the remainder components, which is most times unrealistic.

With the aid of the Breusch-Pagan (Breusch \& Pegan, 1980) Lagrangian Multiplier (BP LM) test, an efficient estimator can be chosen between OLS and RE estimators. The test's null hypothesis is that the variance across units is zero, which implies OLS is efficient. As reported in the main regression results in Table 2, under Revenue share and Expenditure share, the null of no variance across countries is rejected with Chisquared statistics of 6167.78 and 6200.32, respectively, at 1 percent level of significance. Also, in Table 3, for Revenue share and Expenditure share, the null of no variance across countries is rejected with Chisquared statistics of 2964.34 and 2943.75 , respectively, at 1 percent level of significance. This indicates that OLS is not efficient. The Hausman test (1978) can be used to select between the RE and FE estimators. This test is distributed as Chi-squared. The null hypothesis is that the error term's individual component is not correlated with the regressors, in which case FE will be efficient under the null and alternative hypotheses. On the other hand, RE will only be efficient under the null hypothesis. A large difference between the two estimators suggests that the RE estimator is not consistent. From the main regression results in 
Table 2, under Revenue share and Expenditure share, we reject the null of no correlation between the individual error and regressors with Chi-squared statistics of 83.40 and 83.56, respectively, at 1 percent level of significance. Also, in Table 3, under Revenue share and Expenditure share, we reject the null of no correlation between the individual error and regressors with Chi-squared statistics of 50.54 and 44.27 , respectively, at 1 percent level of significance. Thus, the discussion of our results will focus on the FE model.

\subsection{Results}

The results are displayed in Tables 2 and 3. Table 2 displays the results of the effect of decentralisation as measured by revenue share and expenditure share on improved access to sanitation facilities. The results in columns 1 to 3 of Table 2 report the effect of decentralisation as measured by the revenue share on improved access to sanitation services. In contrast, the results in columns 4 to 6 report the effect of decentralisation as measured by the expenditure share on improved access to sanitation facilities. The focus will be on the FE model. FE is the most efficient estimator, which has the merit of exploiting within-country variation and reducing the problem of omitted variable bias. Besides, FE has the lowest root mean square error (RMSE), which indicates that the estimator is more efficient. This is confirmed with the Rho of 1.00 , which implies that almost 100 percent of the variation is due to panel effects. The result in column 2, Table 2 suggests that decentralisation, as measured by revenue share, does improve access to sanitation facilities. Lag revenue share is positive and statistically significant as expected. The result from FE suggests that a 1 percentage point increase in decentralisation leads to an improvement of 0.12 percentage points in access to sanitation services. This implies that an increase in revenues of subnational governments in total government revenues may go into sanitation facilities. The coefficient from OLS is negative, -0.2811 . This may be attributed to the non-usage of country-specific effects in the OLS model. Besides, the RE model's coefficient $(0.1064)$ is close to that of the FE model $(0.1165)$, probably because of our large $T$. This is a pointer that sticking to the FE model in this study is not inappropriate as FE correctly estimates the model.

One major determinant of public outputs is the level of wealth and the average income of any nation. The Log GDP per capita is positive and statistically significant. A 1 percentage increase in income level per capita leads to an increase of 0.10 percentage points in improved access to sanitation services. This suggests that improved access to sanitation facilities will be high in high-income countries. Given the public investment required to improve access to sanitation facilities, this study's data speaks to the situation in many highincome countries, as they have achieved a high level of coverage in improved access to sanitation services. Government size is also positive and statistically significant. This suggests that the size of government is 
positively correlated with improved access to sanitation facilities. This indicates that the large government expenditures may be due to spending on the basic public outputs. The variable Log population density is another driver of the provision of sanitation services. The provision of sanitation services responds to the population density growth according to the a priori expectation.

Though the level of wealth is considered crucial for public outputs, institutional factors may be as important as wealth level. Public institutions' quality and stability are essential in raising the level of welfare and the availability and quality of public services. Democratic accountability is a major institutional factor that indicates the responsiveness of government. The variable is positive and statistically significant. A responsive government will provide essential public goods and services to the people in the right quantity and quality. The coefficient of Democratic accountability from all the estimators further lends credence to the efficiency of FE. The coefficient is negative under OLS, while the coefficient of RE is closed to that of FE. All other variables: Bureaucratic quality, Globalisation, Political competition, Internal conflict, and the interaction term, are not statistically significant.

The result in column 5 of Table 2 describes the positive relationship between decentralisation as measured by expenditure share and improved access to sanitation facilities. The Lag expenditure share is positive and statistically significant. This suggests that a 1 percentage point increase in expenditures of subnational governments in total government expenditures leads to a rise of 0.11 percentage points in improved access to sanitation. Besides, Globalisation also explains improved access to sanitation services. This is a significant driver of the MDGs. The coefficient is positive and marginally statistically significant. The UN's goal, including its agencies in monitoring sanitation facilities is to ensure adequate provision in every nation. All other variables' behaviour is as discussed under the revenue share in terms of improved access to sanitation facilities.

Table 3 displays results for the effect of decentralisation as measured by revenue share and expenditure share on improved access to water sources. The results in columns 1 to 3 of Table 3 report the effect of decentralisation as measured by revenue share on improved access to water sources. The results in columns 4 to 6 report the effect of decentralisation as measured by expenditure share on improved access to water provision. The result in column 2, Table 3 suggests that decentralisation, as measured by revenue share, does have a positive impact on improved access to water sources. The coefficient of the Lag revenue share is positive and statistically significant under FE. The result suggests that a 1 percentage point rise in decentralisation as measured by the proportion of revenues of subnational governments in total government revenues leads to an increase of 0.16 percentage points in improved access to water sources. It is 
noteworthy that this effect is larger than the effect of decentralisation on improved access to sanitation facilities.

Table 2: Effect of decentralisation on improved access to sanitation facilities for all countries

\begin{tabular}{|c|c|c|c|c|c|c|}
\hline \multirow{2}{*}{ Variable } & \multicolumn{3}{|c|}{ Revenue share } & \multicolumn{3}{|c|}{ Expenditure share } \\
\hline & OLS & $\mathrm{FE}$ & RE & OLS & FE & $\mathrm{RE}$ \\
\hline Lag revenue share & $\begin{array}{l}-0.2811^{* \star *} \\
(0.0955)\end{array}$ & $\begin{array}{l}0.1165^{* * \star} \\
(0.0343)\end{array}$ & $\begin{array}{l}0.1064^{* * *} \\
(0.0344)\end{array}$ & & & \\
\hline Lag expenditure share & & & & $\begin{array}{l}-0.2947^{* * *} \\
(0.0986)\end{array}$ & $\begin{array}{l}0.1065^{\star * *} \\
(0.0372)\end{array}$ & $\begin{array}{l}0.0854^{* *} \\
(0.0379)\end{array}$ \\
\hline Government size & $\begin{array}{c}0.5041^{\star \star} \\
(0.1916)\end{array}$ & $\begin{array}{l}0.2794^{* * *} \\
(0.0976)\end{array}$ & $\begin{array}{l}0.3550^{\star * \star} \\
(0.0878)\end{array}$ & $\begin{array}{l}0.5085^{\star \star} \\
(0.1953)\end{array}$ & $\begin{array}{l}0.2874^{\star * \star} \\
(0.0948)\end{array}$ & $\begin{array}{l}0.3616^{\star \star \star *} \\
(0.0852)\end{array}$ \\
\hline Log GDP per capita & $\begin{array}{l}8.8940^{\star * \star} \\
(2.5898)\end{array}$ & $\begin{array}{l}9.6252^{\star * \star} \\
(2.3844)\end{array}$ & $\begin{array}{l}8.5487^{\star * \star} \\
(2.1650)\end{array}$ & $\begin{array}{l}9.2678^{\star \star \star *} \\
(2.6090)\end{array}$ & $\begin{array}{l}9.0562^{* * \star} \\
(2.3666)\end{array}$ & $\begin{array}{l}8.0791^{\text {*** }} \\
(2.1597)\end{array}$ \\
\hline Log pop. density & $\begin{array}{c}0.5690 \\
(1.1046)\end{array}$ & $\begin{array}{l}16.1601^{\text {*** }} \\
(4.8360)\end{array}$ & $\begin{array}{l}6.7156^{\star \star \star} \\
(2.0562)\end{array}$ & $\begin{array}{c}0.4956 \\
(1.1228)\end{array}$ & $\begin{array}{l}16.1943^{\star \star *} \\
(4.9022)\end{array}$ & $\begin{array}{l}6.5620^{\text {***}} \\
(2.0654)\end{array}$ \\
\hline Bureaucratic quality & $\begin{array}{l}-1.6818 \\
(2.2996)\end{array}$ & $\begin{array}{c}0.3367 \\
(0.5455)\end{array}$ & $\begin{array}{c}0.3069 \\
(0.6373)\end{array}$ & $\begin{array}{l}-1.6897 \\
(2.2279)\end{array}$ & $\begin{array}{c}0.4255 \\
(0.5638)\end{array}$ & $\begin{array}{c}0.3589 \\
(0.6772)\end{array}$ \\
\hline Democratic acct. & $\begin{array}{l}-2.1443^{\star \star} \\
(1.0061)\end{array}$ & $\begin{array}{l}0.9047^{\text {***}} \\
(0.2611)\end{array}$ & $\begin{array}{l}0.8625^{\star * *} \\
(0.3044)\end{array}$ & $\begin{array}{l}-2.2376^{\star \star} \\
(1.0061)\end{array}$ & $\begin{array}{l}0.9923^{* * *} \\
(0.2621)\end{array}$ & $\begin{array}{l}0.9398^{* * *} \\
(0.3063)\end{array}$ \\
\hline Globalisation & $\begin{array}{c}0.2815 \\
(0.1798)\end{array}$ & $\begin{array}{c}0.0978 \\
(0.0630)\end{array}$ & $\begin{array}{c}0.0953 \\
(0.0626)\end{array}$ & $\begin{array}{c}0.2748 \\
(0.1794)\end{array}$ & $\begin{array}{c}0.1143^{*} \\
(0.0636)\end{array}$ & $\begin{array}{c}0.1101^{*} \\
(0.0630)\end{array}$ \\
\hline Political competition & $\begin{array}{l}-6.8941 \\
(6.0480)\end{array}$ & $\begin{array}{l}-2.8950 \\
(2.8079)\end{array}$ & $\begin{array}{l}-2.6578 \\
(2.9443)\end{array}$ & $\begin{array}{l}-5.7634 \\
(5.5173)\end{array}$ & $\begin{array}{l}-2.3775 \\
(2.4787)\end{array}$ & $\begin{array}{l}-2.3197 \\
(2.6278)\end{array}$ \\
\hline Internal conflict & $\begin{array}{l}1.9545^{\star \star \star} \\
(0.6704)\end{array}$ & $\begin{array}{l}-0.0663 \\
(0.1417)\end{array}$ & $\begin{array}{c}0.0704 \\
(0.1462)\end{array}$ & $\begin{array}{l}2.0472^{\star \star \star} \\
(0.6808)\end{array}$ & $\begin{array}{l}-0.0897 \\
(0.1484)\end{array}$ & $\begin{array}{c}0.0595 \\
(0.1514)\end{array}$ \\
\hline Competition*revshare & $\begin{array}{l}0.4691^{\star \star} \\
(0.2042)\end{array}$ & $\begin{array}{l}-0.0032 \\
(0.1440)\end{array}$ & $\begin{array}{l}-0.0226 \\
(0.1395)\end{array}$ & & & \\
\hline Competition*expshare & & & & $\begin{array}{c}0.4787^{\star \star} \\
(0.2028)\end{array}$ & $\begin{array}{l}-0.0560 \\
(0.1546)\end{array}$ & $\begin{array}{l}-0.0668 \\
(0.1516)\end{array}$ \\
\hline Observation & 1,022 & 1,022 & 1,022 & 1,023 & 1,023 & 1,023 \\
\hline $\mathrm{R}^{2}$ & 0.72 & 0.68 & 0.41 & 0.72 & 0.67 & 0.41 \\
\hline RMSE & 8.93 & 1.39 & 1.54 & 8.90 & 1.41 & 1.56 \\
\hline Rho & & 1.00 & 0.98 & & 1.00 & 0.98 \\
\hline F Test & $8.70^{\star * *}$ & $8.56^{* * *}$ & & $9.22^{\star * *}$ & $8.75^{\star * *}$ & \\
\hline Wald (Chi2) & & & $198.44^{* * *}$ & & & $196.87^{\star \star *}$ \\
\hline Hausman Test & & $83.40^{* * *}$ & & & $83.56^{\star * *}$ & \\
\hline BP LM Test & & & $6167.78^{* * *}$ & & & $6200.32^{\star \star \star}$ \\
\hline
\end{tabular}

Significance levels: ${ }^{*}: 10 \%,{ }^{* \star}: 5 \%,{ }^{* *}: 1 \%$. Clustered robust standard errors at the country level in parentheses. The dependent variable is the improved access to sanitation. Results in columns 1 to 3 are based on a year lag of revenue share as a measure of decentralisation. In contrast, results in columns 4 to 6 are based on a year lag of expenditure share as a measure of decentralisation. Revenue share is the ratio of revenues of subnational governments to total government revenues, while expenditure share is the ratio of expenditures of subnational governments to total government expenditures. All measures are indicated above the estimators. Log pop. density refers to log population density. Democratic acct. means democratic accountability. The interaction terms are political competition multiplied by revenue share and expenditure share, respectively. RMSE means root mean square error, while BP LM test implies Breusch-Pagan Lagrangian Multiplier test. F test indicates the model's overall significance with the null hypothesis that a model with no independent variable fits the data better. Wald (Chi2) is also a test of overall significance applied to the RE model with a null hypothesis that the regressors are zero. The year effects are dummies included in all the estimators to capture the variation over the years. The year fixed effects are not statistically significant under OLS estimator in columns 1 and 4 using the postestimation command of testparm (StataCorp, 2017). The number of countries included in the models is 66. Source: Author's computation. 
Table 3: Effect of decentralisation on improved access to water sources for all countries

\begin{tabular}{|c|c|c|c|c|c|c|}
\hline \multirow{2}{*}{ Variable } & \multicolumn{3}{|c|}{ Revenue share } & \multicolumn{3}{|c|}{ Expenditure share } \\
\hline & OLS & $\mathrm{FE}$ & $\mathrm{RE}$ & OLS & $\mathrm{FE}$ & $\mathrm{RE}$ \\
\hline Lag revenue share & $\begin{array}{l}-0.0112 \\
(0.0318)\end{array}$ & $\begin{array}{l}0.1561^{* * *} \\
(0.0524)\end{array}$ & $\begin{array}{l}0.1301^{\text {***}} \\
(0.0463)\end{array}$ & & & \\
\hline Lag expenditure share & & & & $\begin{array}{l}-0.0138 \\
(0.0313)\end{array}$ & $\begin{array}{l}0.1280^{* *} \\
(0.0508)\end{array}$ & $\begin{array}{c}0.0905^{*} \\
(0.0475)\end{array}$ \\
\hline Government size & $\begin{array}{l}0.2986^{* * *} \\
(0.0925)\end{array}$ & $\begin{array}{c}0.1183 \\
(0.0890)\end{array}$ & $\begin{array}{c}0.1078 \\
(0.1126)\end{array}$ & $\begin{array}{l}0.2946^{* * *} \\
(0.0917)\end{array}$ & $\begin{array}{c}0.1212 \\
(0.0912)\end{array}$ & $\begin{array}{c}0.1126 \\
(0.1173)\end{array}$ \\
\hline Log GDP per capita & $\begin{array}{l}3.5453^{\star \star \star} \\
(0.8950)\end{array}$ & $\begin{array}{l}6.7027^{\star \star \star} \\
(2.2265)\end{array}$ & $\begin{array}{l}3.5404^{\star \star \star} \\
(1.3555)\end{array}$ & $\begin{array}{l}3.4943^{\star \star \star} \\
(0.8786)\end{array}$ & $\begin{array}{l}6.3386^{\star \star \star} \\
(2.2707)\end{array}$ & $\begin{array}{l}3.2962^{\star \star} \\
(1.4074)\end{array}$ \\
\hline Log pop. density & $\begin{array}{c}0.8855 \\
(0.6001)\end{array}$ & $\begin{array}{c}7.3447 \\
(5.5104)\end{array}$ & $\begin{array}{l}1.8011^{\star \star} \\
(0.8655)\end{array}$ & $\begin{array}{c}0.8821 \\
(0.6019)\end{array}$ & $\begin{array}{l}7.9109 \\
(5.6698)\end{array}$ & $\begin{array}{c}1.7319^{\star} \\
(0.8903)\end{array}$ \\
\hline Bureaucratic quality & $\begin{array}{l}-0.7262 \\
(0.7909)\end{array}$ & $\begin{array}{c}0.0193 \\
(0.3837)\end{array}$ & $\begin{array}{l}-0.2177 \\
(0.4361)\end{array}$ & $\begin{array}{l}-0.7187 \\
(0.7892)\end{array}$ & $\begin{array}{c}0.1153 \\
(0.4713)\end{array}$ & $\begin{array}{l}-0.1737 \\
(0.5227)\end{array}$ \\
\hline Democratic acct. & $\begin{array}{l}-0.5196 \\
(0.4017)\end{array}$ & $\begin{array}{l}0.8114^{\star \star \star} \\
(0.2805)\end{array}$ & $\begin{array}{l}0.7402^{* \star} \\
(0.2954)\end{array}$ & $\begin{array}{l}-0.4823 \\
(0.4034)\end{array}$ & $\begin{array}{l}0.9184^{\star \star \star} \\
(0.2919)\end{array}$ & $\begin{array}{l}0.8243^{\text {*** }} \\
(0.3087)\end{array}$ \\
\hline Globalisation & $\begin{array}{c}0.0749 \\
(0.0720)\end{array}$ & $\begin{array}{l}0.1417^{\star \star} \\
(0.0697)\end{array}$ & $\begin{array}{l}0.1487^{\star *} \\
(0.0701)\end{array}$ & $\begin{array}{c}0.0801 \\
(0.0723)\end{array}$ & $\begin{array}{l}0.1603^{* *} \\
(0.0755)\end{array}$ & $\begin{array}{l}0.1627^{\star *} \\
(0.0753)\end{array}$ \\
\hline Political competition & $\begin{array}{l}-6.2556^{\star \star} \\
(3.0337)\end{array}$ & $\begin{array}{l}-1.1776 \\
(1.9940)\end{array}$ & $\begin{array}{l}-0.5455 \\
(2.0700)\end{array}$ & $\begin{array}{l}-6.1638^{\star \star} \\
(2.7997)\end{array}$ & $\begin{array}{l}-1.4201 \\
(1.8251)\end{array}$ & $\begin{array}{l}-1.0856 \\
(1.9655)\end{array}$ \\
\hline Internal conflict & $\begin{array}{c}0.4437 \\
(0.3704)\end{array}$ & $\begin{array}{l}-0.3026^{*} \\
(0.1754)\end{array}$ & $\begin{array}{l}-0.1879 \\
(0.2011)\end{array}$ & $\begin{array}{c}0.4411 \\
(0.3759)\end{array}$ & $\begin{array}{l}-0.3257^{\star} \\
(0.1882)\end{array}$ & $\begin{array}{l}-0.1899 \\
(0.2121)\end{array}$ \\
\hline Competition*revshare & $\begin{array}{l}0.2094^{\star \star} \\
(0.1003)\end{array}$ & $\begin{array}{c}0.0195 \\
(0.1096)\end{array}$ & $\begin{array}{l}-0.0320 \\
(0.0934)\end{array}$ & & & \\
\hline Competition*expshare & & & & $\begin{array}{l}0.2360^{\star \star} \\
(0.1009)\end{array}$ & $\begin{array}{c}0.0216 \\
(0.1166)\end{array}$ & $\begin{array}{l}-0.0156 \\
(0.1035)\end{array}$ \\
\hline Observation & 1,033 & 1,033 & 1,033 & 1,034 & 1,034 & 1,034 \\
\hline $\mathrm{R}^{2}$ & 0.67 & 0.61 & 0.49 & 0.67 & 0.59 & 0.50 \\
\hline RMSE & 4.09 & 1.31 & 1.45 & 4.09 & 1.35 & 1.49 \\
\hline Rho & & 0.99 & 0.89 & & 0.99 & 0.89 \\
\hline F Test & $10.16^{\star \star \star}$ & $8.96^{\star \star \star}$ & & $10.20^{\star \star \star}$ & $8.13^{\star \star \star}$ & \\
\hline Wald (Chi2) & & & $353.43^{* * *}$ & & & $301.51^{\star \star \star}$ \\
\hline $\begin{array}{l}\text { Hausman Test } \\
\text { BP LM Test }\end{array}$ & & $50.54^{* \star *}$ & $296434^{* * *}$ & & $44.27^{\star \star \star}$ & $294375^{* \star *}$ \\
\hline
\end{tabular}

Significance levels: ${ }^{\star}: 10 \%,{ }^{\star \star}: 5 \%,{ }^{* \star \star}: 1 \%$. Clustered robust standard errors at the country level in parentheses. The dependent variable is the improved access to water. Results in columns 1 to 3 are based on a year lag of revenue share as a measure of decentralisation. In contrast, results in columns 4 to 6 are based on a year lag of expenditure share as a measure of decentralisation. Revenue share is the ratio of revenues of subnational governments to total government revenues, while expenditure share is the ratio of expenditures of subnational governments to total government expenditures. All measures are indicated above the estimators. Log pop. density refers to log population density. Democratic acct. means democratic accountability. The interaction terms are political competition multiplied by revenue share and expenditure share, respectively. RMSE means root mean square error, while BP LM test implies Breusch-Pagan Lagrangian Multiplier test. F test indicates the model's overall significance with the null hypothesis that a model with no independent variable fits the data better. Wald (Chi2) is also a test of overall significance applied to the RE model with a null hypothesis that the regressors are zero. The year effects are dummies included in all the estimators to capture the variation over the years. The year fixed effects are not statistically significant under OLS estimator in column 4 using the postestimation command of testparm (StataCorp, 2017). The number of countries included in the models is 67. Source: Author's computation.

The effect of Government size on improved access to water sources is not statistically significant under the FE in column 2 of Table 3, unlike under the effect of decentralisation as measured by revenue share on improved access to sanitation facilities. Log GDP per capita is positive and significantly correlated with improved access to water sources. A 1 percentage increase in income level per capita leads to a rise of 0.07 percentage points in improved access to water provision. The level of wealth of a nation is a significant 
determinant of improved access to water sources. The sign of the associated coefficients with both $\log$ population density and Bureaucratic quality is positive, but the coefficients are not statistically significant. However, Democratic accountability is positive and statistically significant. The responsiveness of government is relevant to improved access to water provision. The coefficient of globalisation is positive and statistically significant, which implies improved access to water sources responds to globalisation. This can be linked with the universal declaration of targets for the MDGs by the UN. The coefficient of Political competition is negative, but it is not statistically significant. The coefficient of internal conflict is negative and statistically significant, as expected. In the absence of peace, there can be no progress. This extends to the provision of basic services for human existence, such as water.

The focus is on the impact of decentralisation as measured by expenditure share on improved access to water sources. The result in column 5, Table 3 points at a positive and statistically significant relationship between decentralisation as measured by expenditure share and improved access to water sources. The result of the Lag expenditure share under the FE suggests that a 1 percentage point increase in decentralisation as measured by the proportion of expenditures of subnational governments in total government expenditures leads to a rise of 0.13 percentage points in improved access to water. The behaviour of the variables under the expenditure share is similar to the variables' behaviour under the revenue share for improved access to water sources. The variables behave the same way under both revenue share and expenditure in magnitude and direction, as the results from columns 2 and 5 of Table 3 indicate. ${ }^{9}$

\footnotetext{
- For FE models reported in Tables 2 and 3, the interaction terms were removed to see the effect on Political competition and other coefficients in the models. The variable Political competition is negative and statistically significant for the effect of decentralisation on improved access to sanitation facilities under both revenue share and expenditure share. On the other hand, there is no significant change in the magnitude of the other covariates. But for the effect of decentralisation on improved access to water under both revenue share and expenditure share, Political competition is negative, but it is not statistically significant as expected. These results are not reported here.
} 
Table 4: Effect of decentralisation on improved access to sanitation facilities in rural and urban areas

\begin{tabular}{|c|c|c|c|c|}
\hline \multirow{2}{*}{ Variable } & \multicolumn{2}{|c|}{ Rural } & \multicolumn{2}{|c|}{ Urban } \\
\hline & Revshare & Expshare & Revshare & Expshare \\
\hline Lag revenue share & $\begin{array}{l}0.1368^{* * *} \\
(0.0506)\end{array}$ & & $\begin{array}{l}0.0655^{\star \star \star} \\
(0.0241)\end{array}$ & \\
\hline Lag expenditure share & & $\begin{array}{l}0.1487^{* *} \\
(0.0655)\end{array}$ & & $\begin{array}{l}0.0531^{* *} \\
(0.0245)\end{array}$ \\
\hline Government size & $\begin{array}{l}0.4668^{* \star \star} \\
(0.1510)\end{array}$ & $\begin{array}{l}0.4857^{\star \star \star} \\
(0.1489)\end{array}$ & $\begin{array}{l}0.1234^{\star \star} \\
(0.0577)\end{array}$ & $\begin{array}{l}0.1285^{\star \star} \\
(0.0563)\end{array}$ \\
\hline Log GDP per capita & $\begin{array}{l}13.0003^{* * *} \\
(3.4508)\end{array}$ & $\begin{array}{l}12.6659^{* * *} \\
(3.4768)\end{array}$ & $\begin{array}{l}4.7688^{* \star \star} \\
(1.3997)\end{array}$ & $\begin{array}{l}4.5310^{* * *} \\
(1.3942)\end{array}$ \\
\hline Log population density & $\begin{array}{l}18.9579 * \star \\
(7.6078)\end{array}$ & $\begin{array}{l}19.2133^{* *} \\
(7.5705)\end{array}$ & $\begin{array}{l}9.5482^{\star \star \star} \\
(2.8008)\end{array}$ & $\begin{array}{l}9.6384^{* * *} \\
(2.9234)\end{array}$ \\
\hline Bureaucratic quality & $\begin{array}{c}1.0413 \\
(1.1045)\end{array}$ & $\begin{array}{c}1.2050 \\
(1.1324)\end{array}$ & $\begin{array}{c}0.6483^{*} \\
(0.3751)\end{array}$ & $\begin{array}{c}0.7003^{*} \\
(0.4094)\end{array}$ \\
\hline Democratic accountability & $\begin{array}{l}1.2457^{* * *} \\
(0.4168)\end{array}$ & $\begin{array}{l}1.3377^{\star \star \star} \\
(0.4160)\end{array}$ & $\begin{array}{l}0.4752^{\star \star \star} \\
(0.1495)\end{array}$ & $\begin{array}{l}0.5266^{\text {***}} \\
(0.1505)\end{array}$ \\
\hline Globalisation & $\begin{array}{c}0.1846^{*} \\
(0.1044)\end{array}$ & $\begin{array}{c}0.2012^{*} \\
(0.1040)\end{array}$ & $\begin{array}{c}0.0335 \\
(0.0315)\end{array}$ & $\begin{array}{c}0.0417 \\
(0.0321)\end{array}$ \\
\hline Political competition & $\begin{array}{l}-2.0383 \\
(3.1211)\end{array}$ & $\begin{array}{l}-1.7431 \\
(2.6303)\end{array}$ & $\begin{array}{l}-0.1050 \\
(1.5175)\end{array}$ & $\begin{array}{l}-0.0977 \\
(1.3570)\end{array}$ \\
\hline Internal conflict & $\begin{array}{l}-0.1874 \\
(0.2351)\end{array}$ & $\begin{array}{l}-0.2300 \\
(0.2385)\end{array}$ & $\begin{array}{l}-0.0144 \\
(0.0875)\end{array}$ & $\begin{array}{l}-0.0235 \\
(0.0922)\end{array}$ \\
\hline Competition*revshare & $\begin{array}{l}-0.0242 \\
(0.1969)\end{array}$ & & $\begin{array}{l}-0.0448 \\
(0.0877)\end{array}$ & \\
\hline Competition*expshare & & $\begin{array}{l}-0.0604 \\
(0.1991)\end{array}$ & & $\begin{array}{l}-0.0631 \\
(0.0969)\end{array}$ \\
\hline Observation & 1,022 & 1,023 & 1,023 & 1,024 \\
\hline $\mathrm{R}^{2}$ & 0.62 & 0.62 & 0.63 & 0.63 \\
\hline RMSE & 2.32 & 2.32 & 0.79 & 0.80 \\
\hline Rho & 0.99 & 0.99 & 1.00 & 1.00 \\
\hline F Test & 15.79 & 23.81 & 5.49 & 4.99 \\
\hline Hausman Test & $61.60^{* * *}$ & $62.11^{* * *}$ & $61.53^{\star \star \star}$ & $60.89 * * *$ \\
\hline
\end{tabular}

Significance levels: ${ }^{\star}: 10 \%,{ }^{* \star}: 5 \%,{ }^{* * \star}: 1 \%$. Clustered robust standard errors at the country level in parentheses. The dependent variable is the improved access to sanitation facilities. Results in columns 1 and 2 under Rura/ are estimated using the proportion of the rural population with improved access to sanitation. In contrast, the results under Urban in columns 3 and 4 are estimated using the proportion of the urban population with improved access to sanitation. Revshare means revenue share as a measure of decentralisation, the ratio of revenues of subnational governments to total government revenues; while Expshare refers to expenditure share as a measure of decentralisation, the ratio of expenditures of subnational governments to total government expenditures. All measures of decentralisation are lagged by one year in the reported estimates. The reported results are estimated using fixed effects (FE) estimator. The interaction terms are political competition multiplied by revenue share and expenditure share, respectively. RMSE means root mean square error. F test indicates the model's overall significance with the null hypothesis that a model with no independent variable fits the data better. The number of countries included in the reported results is 66. The year effects are dummies included in all the estimators to capture the variation over the years. The year fixed effects are statistically significant for all reported results under FE using the postestimation command of testparm (StataCorp, 2017). Source: Author's computation. 
Table 5: Effect of decentralisation on improved access to water sources in rural and urban areas

\begin{tabular}{|c|c|c|c|c|}
\hline \multirow{2}{*}{ Variable } & \multicolumn{2}{|c|}{ Rural } & \multicolumn{2}{|c|}{ Urban } \\
\hline & Revshare & Expshare & Revshare & Expshare \\
\hline Lag revenue share & $\begin{array}{l}0.2714^{* * \star} \\
(0.0840)\end{array}$ & & $\begin{array}{c}0.0340 \\
(0.0213)\end{array}$ & \\
\hline Lag expenditure share & & $\begin{array}{l}0.2524^{\star \star \star} \\
(0.0943)\end{array}$ & & $\begin{array}{c}0.0222 \\
(0.0218)\end{array}$ \\
\hline Government size & $\begin{array}{c}0.1851 \\
(0.1760)\end{array}$ & $\begin{array}{c}0.1979 \\
(0.1771)\end{array}$ & $\begin{array}{c}0.0105 \\
(0.0333)\end{array}$ & $\begin{array}{c}0.0157 \\
(0.0338)\end{array}$ \\
\hline Log GDP per capita & $\begin{array}{l}10.1179 * * \star \\
(3.1489)\end{array}$ & $\begin{array}{l}10.0165^{* * *} \\
(3.2383)\end{array}$ & $\begin{array}{l}1.9142^{* *} \\
(0.9211)\end{array}$ & $\begin{array}{c}1.8090 * \\
(0.9188)\end{array}$ \\
\hline Log population density & $\begin{array}{c}7.8083 \\
(9.7161)\end{array}$ & $\begin{array}{c}9.5026 \\
(9.8787)\end{array}$ & $\begin{array}{c}3.4267 \\
(2.1877)\end{array}$ & $\begin{array}{c}3.3857 \\
(2.2380)\end{array}$ \\
\hline Bureaucratic quality & $\begin{array}{c}1.4120 \\
(1.0001)\end{array}$ & $\begin{array}{c}1.6869 \\
(1.1109)\end{array}$ & $\begin{array}{c}0.0354 \\
(0.1810)\end{array}$ & $\begin{array}{c}0.0584 \\
(0.1953)\end{array}$ \\
\hline Democratic accountability & $\begin{array}{l}1.4902^{* * *} \\
(0.4333)\end{array}$ & $\begin{array}{l}1.6621^{\text {***}} \\
(0.4506)\end{array}$ & $\begin{array}{c}0.1880 \\
(0.1391)\end{array}$ & $\begin{array}{c}0.2201 \\
(0.1404)\end{array}$ \\
\hline Globalisation & $\begin{array}{c}0.2598^{* *} \\
(0.1284)\end{array}$ & $\begin{array}{c}0.2857^{* *} \\
(0.1382)\end{array}$ & $\begin{array}{c}0.0254 \\
(0.0214)\end{array}$ & $\begin{array}{c}0.0300 \\
(0.0224)\end{array}$ \\
\hline Political competition & $\begin{array}{c}0.3202 \\
(2.9989)\end{array}$ & $\begin{array}{l}-0.7117 \\
(2.2754)\end{array}$ & $\begin{array}{c}0.2912 \\
(0.7104)\end{array}$ & $\begin{array}{c}0.1492 \\
(0.6598)\end{array}$ \\
\hline Internal conflict & $\begin{array}{l}-0.5105^{\star} \\
(0.2923)\end{array}$ & $\begin{array}{l}-0.5710^{*} \\
(0.3157)\end{array}$ & $\begin{array}{l}-0.1396^{* *} \\
(0.0650)\end{array}$ & $\begin{array}{l}-0.1417^{* *} \\
(0.0685)\end{array}$ \\
\hline Competition*revshare & $\begin{array}{c}0.0148 \\
(0.1782)\end{array}$ & & $\begin{array}{l}-0.0396 \\
(0.0393)\end{array}$ & \\
\hline Competition ${ }^{*}$ expshare & & $\begin{array}{c}0.0690 \\
(0.1687)\end{array}$ & & $\begin{array}{l}-0.0415 \\
(0.0467)\end{array}$ \\
\hline Observation & 1,033 & 1,034 & 1,035 & 1,036 \\
\hline $\mathrm{R}^{2}$ & 0.57 & 0.56 & 0.40 & 0.39 \\
\hline RMSE & 2.57 & 2.61 & 0.54 & 0.54 \\
\hline Rho & 0.97 & 0.97 & 0.99 & 0.99 \\
\hline F Test & 8.81 & 12.53 & 3.08 & 3.55 \\
\hline Hausman Test & $72.44^{* * *}$ & $65.98^{* * *}$ & 10.95 & 11.86 \\
\hline
\end{tabular}

Significance levels: ${ }^{\star}: 10 \%,{ }^{* \star}: 5 \%,{ }^{* \star *}: 1 \%$. Clustered robust standard errors at the country level in parentheses. The dependent variable is the improved access to water sources. Results in columns 1 and 2 under Rura/are estimated using the proportion of the rural population with improved access to water. In contrast, the results under Urban in columns 3 and 4 are estimated using the proportions of the urban population with improved access to water. Revshare means revenue share as a measure of decentralisation, the ratio of revenues of subnational governments to total government revenues; while Expshare refers to expenditure share as a measure of decentralisation, the ratio of expenditures of subnational governments to total government expenditures. All measures of decentralisation are lagged by one year in the reported estimates. The reported results are estimated using fixed effects (FE) estimator. The interaction terms are political competition multiplied by revenue share and expenditure share, respectively. RMSE means root mean square error. F test indicates the model's overall significance with the null hypothesis that a model with no independent variable fits the data better. The number of countries included in the reported results is 67 . The year effects are dummies included in all the estimators to capture the variation over the years. The year fixed effects are statistically significant for all reported results under FE using the postestimation command of testparm (StataCorp, 2017) except in column 3. For results in columns 3 and 4, the Hausman test is not statistically significant. Source: Author's computation. 


\subsection{Robustness checks}

The robustness checks are conducted to confirm the consistency of the econometric estimates of this study. The dependent variable data, improved access to sanitation and water services measured in percentage of the total population with improved access, is the aggregated data for both urban and rural areas at the country level. The disaggregated data is available for rural and urban areas in every country assessed by the UN's agencies saddled with the data collection on improved access to sanitation facilities and water sources. The goal of decentralisation is to accelerate development, tailor public outputs towards local needs, and bring governance closer to the governed (Oates, 1972,1999). Oates (2002) and Dinan et al. (1999) have maintained that there are welfare losses in the uniform standard's imposition in water provision. This arises from the influence of environmental factors on water quality. Considering this view, it is appropriate to use the disaggregated data, for both rural and urban areas, on improved access to sanitation facilities and water sources measured in percentage of the rural and urban population with improved access to check the robustness of our econometric estimates.

The robustness check is conducted to check if decentralisation impacts improved access to sanitation and water services in rural areas vis-à-vis the country level and urban areas. Decentralisation is expected to bring governance closer to the governed with improvement in public services. In many countries, the presence of government is hardly felt at the subnational level, especially in rural areas, as many rural areas are without basic amenities (Zewari et al., 2011). The results from the robustness checks where the dependent variable is improved access to sanitation facilities and water sources measured in the percentage of the rural population with improved access are similar to results for the main regression estimates in Tables 2 and 3. The results for the robustness checks are shown in Tables 4 and 5. As in the main regressions, the focus is on the FE estimator's results because it is the most efficient among the estimators explored in the main regressions. The results in Tables 4 and 5 suggest that decentralisation, as measured by revenue share and expenditure share, has a positive impact on improved access to sanitation and water services in rural areas. Both Lag revenue share and Lag expenditure share are positive and statistically significant. The positive effects of decentralisation on improved access to sanitation facilities and improved access to water sources are larger for the rural areas vis-à-vis the country level and urban areas. The results represent an ideal decentralisation system where resources are devolved to subnational governments in terms of subnational revenue share and expenditure share in total government revenues and expenditures. This presupposes that the subnational government can take fiscal decisions without interference from the central government.

The results support the decentralisation of governance architecture in meeting the demands for the provision 
of essential services such as water and sanitation services at subnational levels. When the government is moved closer to the people, there is a likelihood of improvement in public services outputs. The econometric estimation results indicate that the behaviour of the variables is similar in magnitude and direction as in the main regression estimates. Still, the coefficients of decentralisation are larger for rural areas. In all, the results of robustness checks suggest decentralisation correlates positively with improved access to sanitation facilities and water sources. However, political competition is not statistically significant under the FE estimator across measures of decentralisation. The interaction term's effect is also not distinguishable across measures of decentralisation for the FE estimates for main regressions and robustness checks. Even so, attempts are made to distinguish the effect through margin plots, but the results remain the same. ${ }^{10}$

\section{Conclusion}

This study examines the impact of decentralisation on improved access to sanitation facilities and water sources. The decentralised governance architecture promises an efficient delivery of public goods where it engenders healthy competition among various government levels, particularly at the horizontal level. The primary goal of decentralisation is to bring governance close to the governed. Given this fact, governments at the local level may be better positioned to make services delivery to the people (Oates 1972, 1999). Decentralisation may be better in addressing unavailability and unimproved drinking water and poor sanitation at the subnational level in many countries. The decentralised governance mechanism takes into consideration the heterogeneity of interests in any geopolitical setting. This system encourages bottom-up approaches in addressing developmental challenges by giving recognition to the regional and environmental realities. More so, the effects of environmental conditions on the quality of drinking water and sewerage management suggest decentralisation may help resolve the challenges hindering the provision of these services. This approach will ensure that services suit the circumstances of each jurisdiction. This is in line with the views expressed by Oates (2002) and Dinan et al. (1999).

Decentralisation increases governance quality (Kyriacon \& Rosa-Segalés, 2011) and trust in government (Lightart \& Oudheusden, 2015) because local people are saddled with their jurisdictional governance. Under a decentralised governance arrangement, various jurisdictions will strive to improve drinking water and sanitation services, given the knock-on effects of these essential services. In terms of the fiscal capacity and

\footnotetext{
${ }_{10}^{10}$ Theoretically, the regression estimates are adequate to identify the effects of interaction terms in linear models. But we choose to go the extra mile to identify the effects of the interaction terms in our models through margin plots. The information provided by the margin plots is not different from the estimates of our regressions concerning either the effect of revenue/expenditure share on the two states of competition or the effect of competition for different values of revenue/expenditure share. The margin plots are not shown here.
} 
autonomy of subnational governments, the degree of decentralisation is important for the provision of services. The more the proportion of the fiscal resources at the subnational levels, the higher is the capacity to provide essential services to meet local demands. The results from this study strengthen the support for a system of decentralisation in governance. Besides, institutional factors matter for improved access to water and sanitation services. An accountable government will work hard to improve access to sanitation facilities and water sources. In the absence of peace, no development can take place. Nations that are experiencing civil strife cannot meet the needs of the populations. Conflicts make it impossible to improve access to sanitation and water services. Globalisation is also a significant driver of improved access to sanitation and water provision. This may have been driven by the United Nations' declaration and campaign to eliminate poor access to sanitation facilities and improved water sources worldwide, especially in developing countries.

However, decentralisation in many developing countries is bedevilled with many challenges, including corruption and local capture (Prud'homme, 1995; Reinikka \& Svensson, 2004). The grants to subnational levels from the central government are sometimes cornered for the elites' selfish gains at the local level. Furthermore, decentralisation is most times lopsided in developing countries (Prud'homme, 1995). Revenues tend to be shared, favouring the central government, while expenditures tend to be decentralised at the lower level. This may have significant negative effects on the provision of services. As Ahmad et al. (2006) suggested, various instruments of decentralisation facing service providers at the local level may alter their incentives for the provision of services. Notwithstanding the challenges of decentralisation, it appears a better governance architecture to improve services at the local level. The effect of decentralisation on improved access to water and sanitation services is larger in the rural areas vis-à-vis the country level and urban areas. By and large, our results suggest that decentralisation improve access to sanitation facilities and water sources.

\section{References}

Ahmad, J., Devarajan, S., Khemani, S., \& Shah, S. (2006). Decentralisation and service delivery. In E. Ahmad \& G. Brosio (Eds.), Handbook of Fiscal Federalism (pp. 240-268). Cheltenham, UK: Edward Elgar.

Aidt, T. S., \& Eterovic, D. S. (2011). Political competition, electoral participation and public finance in 20th century Latin America. European Journal of Political Economy, 271), 181-200.

Alsan, M., \& Goldin, C. (2019). Watersheds in infant mortality: The role of effective water and sewerage infrastructure, 1880 to 1920. Journal of Political Economy, 127(2), 586-638. 
Arvate, P. R. (2013). Electoral competition and local government responsiveness in Brazil. World Development, 43(C), 67-83.

Asfaw, A., Frohberg, K., James, K. S., \& Jütting, J. (2007). Fiscal decentralization and infant mortality: Empirical evidence from rural india. The Journal of Developing Areas, 41(1), 17-35.

Asthana, A. N. (2003). Decentralisation and supply efficiency: The case of rural water supply in Central India. Journal of Development Studies, 39(4), 148-159.

Awuah, E., Nyarko, K. B., \& Owusu, P. A. (2009). Water and sanitation in Ghana. Desalination, 248(1-3), 460-467.

Barankay, I., \& Lockwood, B. (2007). Decentralization and the productive efficiency of government: Evidence from Swiss cantons. Journal of Public Economics, 91(5-6), 1197-1218.

Blume, L., \& Voigt, S. (2011). Federalism and decentralization-a critical survey of frequently used indicators. Constitutional Political Economy, 22(3), 238-264.

Breusch, T. S., \& Pagan, A. R. (1980). The Lagrange multiplier test and its applications to model specification in econometrics. The Review of Economic Studies, 471), 239-253.

Brock, G., Jin, Y., \& Zeng, T. (2015). Fiscal decentralization and China's regional infant mortality. Journal of Policy Modeling, 372), 175-188.

Cantarero, D., \& Pascual, M. (2008). Analysing the impact of fiscal decentralization on health outcomes: Empirical evidence from Spain. Applied Economics Letters, 15(2), 109-111.

Chattopadhyay, S. (2012). Decentralisation and delivery of urban basic services: The West Bengal experience. Development in Practice, 22(1), 57-70.

Cleary, M. R. (2007). Electoral competition, participation, and government responsiveness in Mexico. American Journal of Political Science, 51(2), 283-299.

Davoodi, H., \& Zou, H. F. (1998). Fiscal decentralization and economic growth: A Cross-Country Study. Journal of Urban Economics, 43(2), 244-257.

Diaz-Serrano, L., \& Meix-Llop, E. (2012). Do fiscal and political decentralisation raise students' performance? A cross-country analysis. IZA Dicussion Paper No. 6722, 1-36.

Dinan, T., Cropper, M., \& Portney, P. (1999). Environmental federalism: welfare losses from uniform national drinking water standards. In A. Panagariya, P. R. Portney, \& R. M. Schwab (Eds.), Environmental and Public Economics: Essays in Honor of Wallace E. Oates (pp. 13-31). Cheltenham, UK: Edward Elgar.

Dinar, A., Kemper, K., Blomquist, W., \& Kurukulasuriya, P. (2007). Whitewater: Decentralization of river basin water resource management. Journal of Policy Modeling, 296), 851-867.

Dreher, A. (2006). Does globalization affect growth? Evidence from a new index of globalization. Applied Economics, 38(10), 1091-1110.

Dreher, A., \& Fischer, J. A. V. (2010). Government decentralization as a disincentive for transnational terror? an empirical analysis. International Economic Review, 51(4), 981-1002.

Dreher, A., \& Fischer, J. A. V. (2011). Does government decentralization reduce domestic terror? An empirical test. Economics Letters, 111(3), 223-225.

Drukker, D. M. (2003). Testing for serial correlation in linear panel data models. The Stata Journal, 3(2), 168-177. 
Dziobek, C., Mangas, C. G., \& Kufa, P. (2011). Measuring fiscal decentralization - exploring the IMF 's databases. IMF Working Paper 11/26.

Faguet, J. P., \& Sánchez, F. (2014). Decentralization and access to social services in Colombia. Public Choice, 1601-2), 227-249.

Falch, T., \& Fischer, J. A. V. (2012). Public sector decentralization and school performance: International evidence. Economics Letters, 114(3), 276-279.

Gamper-Rabindran, S., Khan, S., \& Timmins, C. (2010). The impact of piped water provision on infant mortality in Brazil: A quantile panel data approach. Journal of Development Economics, 92(2), 188200.

Gemmell, N., Kneller, R., \& Sanz, I. (2013). Fiscal decentralization and economic growth: Spending versus revenue decentralization. Economic Inquiry, 51(4), 1915-1931.

Gómez-Reino, J. L., \& Martinez-Vazquez, J. (2013). An international perspective on the determinants of local government Fragmentation. In S. Lago-Penas \& J. Martinez-Vazquez (Eds.), The Challenge of Local Government Size Theoretical Perspectives, International Experience and Policy Reform (pp. 854). Cheltenham, UK: Edward Elgar.

Granados, C., \& Sánchez, F. (2014). Water Reforms, Decentralization and Child Mortality in Colombia, 1990-2005. World Development, 53, 68-79.

Greene, W. H. (2017). Econometric Analysis, 8th ed. New York: Prentice Hall.

Hausman, J. A. (1978). Specification tests in econometrics. Econometrica, 466), 1251-1271.

Herrera, V. (2014). Does Commercialization Undermine the Benefits of Decentralization for Local Services Provision? Evidence from Mexico's Urban Water and Sanitation Sector. World Development, 56(C), $16-31$.

Hiskey, J. T. (2000). Does democracy matter? Electoral competition and local development in mexico. Prepared for Delivery at the 2000 Meeting of the Latin American Studies Association, Hyatt Regency Miami, March 16-18, 2000.

Hutton, G., \& Varughese, M. (2016). The costs of meeting the 2030 sustainable development goal targets on drinking water, sanitation, and hygiene. World Bank Water and Sanitation Program: Technical Paper No. 103171.

Jaadla, H., \& Puur, A. (2016). The impact of water supply and sanitation on infant mortality: Individuallevel evidence from Tartu, Estonia, 1897-1900. Population Studies, 7a2), 163-179.

Koola, J., \& Zwane, A. P. (2014). Water supply and sanitation. In A. J. Culyer (Ed.), Encyclopedia of health economics (1st ed., pp. 477-482).

Kyriacou, A. P., \& Roca-Sagalés, O. (2011). Fiscal decentralization and government quality in the OECD. Economics Letters, 111(3), 191-193.

Laryea-Adjei, G., \& van Dijk, M. P. (2012). Changing water governance in Ghana through decentralisation. International Journal of Water, 6(3/4), 215.

Ligthart, J. E., \& Van Oudheusden, P. (2015). In government we trust: The role of fiscal decentralization. European Journal of Political Economy, 37(C), 116-128.

Martinez-Vazquez, J., Lago-Peñas, S., \& Sacchi, A. (2017). The impact of fiscal decentralization: A survey. Journal of Economic Suneys, 31(4), 1095-1129. 
Martinez-Vazquez, J., \& Timofeev, A. (2010). Decentralization measures revisited. Public Finance and Management, 101), 13-47.

Montgomery, M. a, \& Elimelech, M. (2007). Water and sanitation in developing countries: Including health in the equation - Millions suffer from preventable illnesses and die every year. Environmental Science and Technology, 41(1), 17-24.

Oates, W. E. (1972). Fiscal federalism. New York: Harcourt Brace Jovanovich.

Oates, W. E. (1999). An essay on fiscal federalism. Journal of Economic Literature, 373), 1120-1149.

Oates, W. E. (2002). The arsenic rule: A case for decentralized standard setting? Resources, 2(147), 1618.

Prud'homme, R. (1995). The dangers of decentralization. The World Bank Research Observer, 192), 201-220.

Ranganathan, M., Kamath, L., \& Baindur, V. (2009, August 15). Piped water supply to greater Bangalore: Putting the cart before the horse? Economic and Political Weekly, 44(33), 53-62.

Reinikka, R., \& Svensson, J. (2004). Local capture: Evidence from a central government transfer program in Uganda. Quarterly Journal of Economics, 119(2), 679-705.

Robalino, D., Picazo, O., \& Voetberg, A. (2001). Does fiscal decentralization improve health outcomes? Evidence from a cross-country analysis. World Bank Policy Research Working Paper No. 2565.

Rodriguez-Pose, A., \& Ezcurra, R. (2011). Is fiscal decentralization harmful for economic growth? Evidence from the OECD countries. Journal of Economic Geography, 11(4), 619-643.

Rosenzweig, S. C. (2015). Does electoral competition affect public goods provision indominant-party regimes? Evidence from Tanzania. Electoral Studies, 39, 72-84.

Rubio, D. J. (2011). The impact of decentralization of health services on health outcomes: Evidence from Canada. Applied Economics, 43(26), 3907-3917.

Sacchi, A., \& Salotti, S. (2014). The effects of fiscal decentralization on household income inequality: Some empirical evidence. Spatial Economic Analysis, 9(2), 202-222.

Sepulveda, C. F., \& Martinez-Vazquez, J. (2011). The consequences of fiscal decentralization on poverty and income equality. Environment and Planning C: Government and Policy, 29(2), 321-343.

Smoke, P., Loffler, G., \& Bosi, G. (2013). The role of decentralisation/devolution in improving development outcomes at the local level: Review of the literature and selected cases. Brooklyn, NY: Local Development International LLC.

Soto, V. E., Farfan, M. I., \& Lorant, V. (2012). Fiscal decentralisation and infant mortality rate: The Colombian case. Social Science and Medicine, 74(9), 1426-1434.

StataCorp. (2017). Stata statistical software: Release 15. College Station, TX: StataCorp LLC

Thiessen, U. (2003). Fiscal decentralisation and economic growth in high-income OECD countries. Fiscal Studies, 24(3), 237-274.

Thornton, J. (2007). Fiscal decentralization and economic growth reconsidered. Journal of Urban Economics, 61(1), 64-70.

Veiga, L. G., Kurian, M., \& Ardakanian, R. (2015). Trends in financing of public services. In (Eds.) Intergovernmental Fiscal Relations: Questions of Accountability and Autonomy (pp. 1-24). New York: Springer 
Verbeek, M. (2017). A guide to modern econometrics, 5th edition. Hoboken, NJ: John Wiley \& Sons Ltd. WHO/UNICEF. (2012). Progress on drinking water and sanitation. Geneva: World Health Organisation. WHO/UNICEF. (2015). Progress on sanitation and drinking water: 2015 update and MDG assessment. Geneva: World Health Organization.

WHO/UNICEF. (2017). WASH in the 2030 Agenda. Geneva: World Health Organization.

WHO. (2008). Un-water global annual assessment of sanitation and drinking-water - 2008 pilot report testing a new reporting approach. Geneva: World Health Organization.

Wooldridge, J. M. (2010). Econometric analysis of cross section and panel data, 2nd ed. Cambridge, Mass.: The MIT Press.

Zawahri, N., Sowers, J., \& Weinthal, E. (2011). The politics of assessment: Water and sanitation MDGs in the Middle East. Development and Change, 42(5), 1153-1178. 


\section{Appendix}

Table A: Definitions and sources of data

\begin{tabular}{|c|c|c|}
\hline Variable & Description & Sources \\
\hline Improved sanitation & $\begin{array}{l}\text { Improved sanitation facilities (\% of } \\
\text { population with access) }\end{array}$ & $\begin{array}{l}\text { United Nations (UN) accessed } \\
\text { through World Bank } \\
\text { Development Indicators (WDI), } \\
2016\end{array}$ \\
\hline Improved water & $\begin{array}{l}\text { Improved water sources (\% of } \\
\text { population with access) }\end{array}$ & $\begin{array}{l}\text { UN accessed through WDI, } \\
2016\end{array}$ \\
\hline $\begin{array}{l}\text { Revenue share } \\
\text { (Revshare) }\end{array}$ & $\begin{array}{l}\text { Subnational government share of } \\
\text { revenues (as \% of total government } \\
\text { revenues) }\end{array}$ & $\begin{array}{l}\text { Government Finance Statistics, } \\
\text { International Monetary Fund } \\
\text { (IMF), } 2016 \text { and author's } \\
\text { computation }\end{array}$ \\
\hline $\begin{array}{l}\text { Expenditure share } \\
\text { (Expshare) }\end{array}$ & $\begin{array}{l}\text { Subnational government share of } \\
\text { expenditures (as \% of total government } \\
\text { expenditure) }\end{array}$ & $\begin{array}{l}\text { GFS, IMF, } 2016 \text { and author's } \\
\text { computation }\end{array}$ \\
\hline Government size & $\begin{array}{l}\text { The ratio of general government final } \\
\text { consumption expenditures (constant } \\
2010 \text { US\$) to gross domestic product } \\
\text { (GDP) multiply by } 100\end{array}$ & $\begin{array}{l}\text { WDI, } 2016 \text { and author's } \\
\text { computation }\end{array}$ \\
\hline Log GDP per capita & $\begin{array}{l}\text { Log of GDP per capita (constant } 2010 \\
\text { US\$) }\end{array}$ & WDI, 2016 \\
\hline Log population density & $\begin{array}{l}\text { Log of the ratio of total population to } \\
\text { the land area of a country in square } \\
\text { kilometre. }\end{array}$ & WDI, 2016 \\
\hline Bureaucratic quality & $\begin{array}{l}\text { Indicator of stability and bureaucratic } \\
\text { quality denoting the risk of policy } \\
\text { reversal. Very high quality }=4 \text {, very low } \\
\text { quality }=0 \text {. }\end{array}$ & $\begin{array}{l}\text { International Country Risk Guide } \\
\text { (ICRG), } 2018\end{array}$ \\
\hline Democratic accountability & $\begin{array}{l}\text { Measure of responsiveness of the } \\
\text { government to its people based on the } \\
\text { prevailing democratic practice. Lowest } \\
\text { risk }=6, \text { highest risk }=1 \text {. }\end{array}$ & ICRG, 2018 \\
\hline Globalisation & $\begin{array}{l}2017 \text { KOF (The Swiss Economic } \\
\text { Institute) index of globalisation }\end{array}$ & Dreher (2006) \\
\hline Internal conflict & $\begin{array}{l}\text { Assessment of countries' internal risk of } \\
\text { political violence effect on governance. } \\
\text { Very high risk }=0 \text {, very low risk }=4 \text {. }\end{array}$ & ICRG, 2018 \\
\hline Political competition & $\begin{array}{l}\text { Polity2 score normalised to a dummy } \\
\text { variable where it takes } 0 \text { for Politity2 } \\
\text { score between }-10 \text { to } 0 \text { and } 1 \text { for } 1 \text { to } \\
10 \text { (Aidt \& Eterovic, 2011). }\end{array}$ & $\begin{array}{l}\text { Polity IV: Regime authority } \\
\text { characteristics and transitions } \\
\text { datasets, Centre for Systemic } \\
\text { Peace, } 2015\end{array}$ \\
\hline
\end{tabular}

Source: Author's compilation. 